\title{
A Family Business Success Map to Enhance the Sustainability of a Multi-Generational Family Business
}

\author{
Ungerer $\mathbf{M}^{*}$ and Mienie $\mathrm{C}$
}

University of Stellenbosch Business School, Bellville, South Africa

Received: January 29, 2018; Accepted: May 24, 2018; Published: June 20, 2018

*Corresponding author: Ungerer M, University of Stellenbosch Business School, Bellville, South Africa E-mail: mariusu@usb.ac.za

\begin{abstract}
Family businesses struggle to be sustainable over multiple generations. In fact, most family businesses do not survive past the second generation. The main aim of this article is to present a conceptual framework which could be used to assist family business enterprises to become sustainable over multi-generations.

The study's focus is on the challenge to sustain a family business over multi-generations. The family business experts used in this study are all based in South Africa.

A two-phased qualitative research approach was used in developing and validating the conceptual framework. In the first phase of development, current literature was used to identify success practices for a multi-generational family business culminating in a preliminary conceptual framework. During the second phase (validation), the resultant preliminary framework for multigenerational sustainability was then reviewed by seven family business experts during a personal interview process. The outcome of this validation process is an integrated framework in the form of a one-page Family Business Success Map (FBSM).
\end{abstract}

The contribution of this study is a conceptual framework in the form of an FBSM that enables family business members, family business advisors, and family business managers to continuously benchmark their business practices in eight key family business practice areas to enhance the potential of a family business to be sustainable across multiple generations.

The FBSM as reflected in this study is not an all-encompassing view on this broad subject matter, but rather a conversation stimulus to explore important management practice leverages to improve the sustainability of a family business over multi-generations.

Key words: Family Business; Family Business Best Practices; Family Business Governance; Family Business Succession Planning; Family Harmony

\section{Introduction}

"Shirtsleeves to shirtsleeves in three generations" [1]. This saying, which originated in the United States of America (USA), refers to the tendency of family-owned enterprises not to be financially sustainable during the reign of the third generation or thereafter. This notion is not unique to the USA and in many countries, this sentiment is echoed. In Brazil, they say: "Pairico, filhonobre, netopobre". Roughly translated, it means rich father, noble son, poor grandson [1]. The Mexicans probably say it the boldest: "father merchant, son gentleman, grandson beggar!" (Lambrecht 2005:267). It is estimated that the average lifespan of a family business is 24 years and that this is more or less the same number of years the founder remained in control of the business.

The lack of sustainability of family businesses over multiple generations is also evident in South Africa. A study by Venter, Van der Merwe and Farrington [6] indicated that the complicated dynamics between family members not only have an impact on their family business but also on its development, growth, and performance over time. According to (3), there are a number of obstacles for family firms to grow and survive in the long term. These demands include normal business challenges such as being part of a business lifecycle, intensifying competition, and new technologies. Another aspect is risk aversion due to high levels of ownership concentration and intentions to maintain family control which influences decisions to take on growth opportunities [5]. However, as families expand and their lifestyle needs increase, it becomes difficult for the family business to grow fast enough to satisfy these needs.

\section{Problem Statement and Objectives}

A family-owned business represents a unique context that is different from non-family-owned businesses. [6] Noted that "The complicated dynamics that exist among family members not only influence the performance of their family business but also its growth, change and transitioning over time". In a study done by [7] on Slovenian enterprises, they found that there is a stronger clan culture in family enterprises than in non-family enterprises. Table 1 shows a summary of some of the most important differences between family businesses and non-family businesses. The dominant influencing role of a family perspective can be seen in most of these differences. (Table 1)

Given the intricate dynamics associated with a family business and as indicated in the introduction, the general acceptance that family businesses struggle to be sustainable over multiple generations, a practice gap to advise family business stakeholders on these aspects exist $[1,3]$. This distinctive challenge of guiding family businesses to be sustainable for multiple generations was the core focus of this study. 
Table 1: Differences between family and non-family businesses

\begin{tabular}{|c|c|c|}
\hline Dimensions & Family business & Non-family business \\
\hline Nature & Emotional & Rational \\
\hline Membership & Involuntary & Voluntary \\
\hline Assessment & Based on norms of loyalty and reciprocity & Based on contribution to the firm \\
\hline Orientation & $\begin{array}{l}\text { Inwardly oriented to protect, nurture, and develop } \\
\text { members }\end{array}$ & Profit oriented \\
\hline Penchant to change & $\begin{array}{l}\begin{array}{l}\text { Views change as a threat to safety and security for } \\
\text { family }\end{array}\end{array}$ & $\begin{array}{l}\text { Views change as an opportunity for growth } \\
\text { and advancement }\end{array}$ \\
\hline
\end{tabular}

There is a need to empower a family business with a simple, yet comprehensive, tool to manage the business for sustained growth from one generation to another. Given the unique challenges associated with a family business to ensure sustainability beyond the founding generation, this study explored key leverages in family business practice areas that can be used to enhance the longevity of a family business over multiple generations.

The main aim of this study was to provides a conceptual framework to assist family business enterprises to become sustainable over multiple generations. The outcome of this study is a Family Business Success Map (FBSM) for family business members, family business advisors, and family business managers to benchmark their business practices in eight key family business practice areas. This continual benchmarking could contribute to enhancing the family business potential for flourishing across multiple generations.

A two-phased approach was used to develop and validate the FBSM. In the first phase, a preliminary conceptual framework was developed based on current literature which identified success practices for a multi-generational family business. During the second phase of validation of the FBSM, the preliminary conceptual framework was reviewed by seven family business experts during face-to-face interviews. This two-phased approach in developing and validating the FBSM is described in this article.

\section{Development and Validation of the Family Business Success Map}

Before describing the development and validation of the FBSM, the research procedure needs to be explained. The main research question of this study was: What are the key leverages in family business practice areas that a family business should consider continuously in order to ensure multi-generational sustainability? The main research question was answered firstly by identifying several family business practice areas through a literature review and secondly by evaluating them and reviewing them through interviews with family business experts. This represents a qualitative research approach to collect and analyse the primary data of this study.

The research was thus done in two main phases. The first phase was the literature review where the focus was on obtaining multiple perspectives about the best practices that successful and sustainable family businesses apply to ensure that their businesses continue from generation to generation. From these views and concepts, a preliminary conceptual framework was developed. The second phase involved the gathering of primary data through interviews with family business experts. In phase two, seven family business experts were interviewed. The interviews were semi-structured and contained open-ended questions on critical success factors as well as closed Likert scale questions on the findings from the preliminary framework. The objective of the interviews was to gather further data which was used to validate and improve the preliminary conceptual framework. The seven family business experts were chosen from three groups where each group represented a different perspective on family businesses (Figure 1).

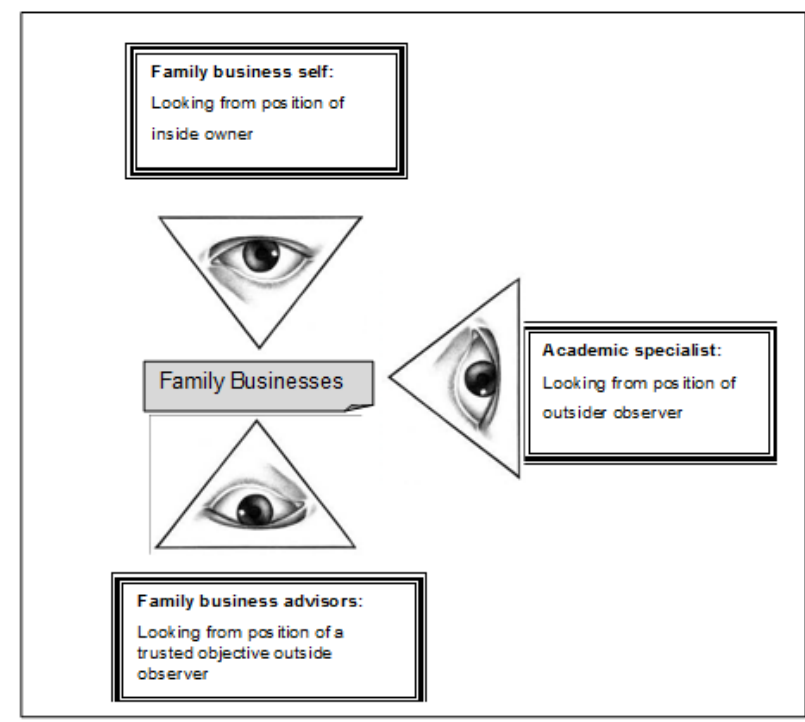

Figure 1: Different perspectives of research respondents

The following selection criteria were used for the three groups of experts interviewed:

1. Expert members of multi-generational family businesses: To qualify as an expert member from a successful family 
business, the family business needed to already have third and fourth generation family members as part of their senior management. The expert member needed to be involved in the family business for more than ten years. The expert member needed to be part of the top management of the family business.

2. Expert family business advisors: Family business advisors needed to be directly involved with different family businesses over a time span of more than ten years. The family businesses they are involved in should have had one or more successful successions.
3. Expert family business academic specialist: A family business academic specialist should have been studying family businesses for more than ten years as part of their academic research. The academic specialist needed to have at least five peer group-reviewed articles on family businesses, published in an academic journal.

A short profile of the family business experts interviewed is reflected in Table 2 . These seven family business experts have a total of 176 years of family business experience among them, with an average of 25 years per expert. (Table 2)

Table 2: Features of family business (FB) experts

\begin{tabular}{|c|c|c|c|c|c|}
\hline \multicolumn{6}{|c|}{ Expert members of successful family businesses } \\
\hline Name & Age & Family business sector scope & Position at family business & FB: Years' experience & Generation \\
\hline Family member 1 & 42 & $\begin{array}{l}\text { Manufacturing and retailing of } \\
\text { agricultural goods }\end{array}$ & Operational Director & 16 & 4 \\
\hline Family member 2 & 59 & Agricultural primary producer & Managing Director & 32 & 5 \\
\hline Family member 3 & 53 & Agricultural primary producer & Managing Director & 33 & 11 \\
\hline Family member 4 & 54 & Monument and granite business & Managing Director & 29 & 4 \\
\hline \multicolumn{6}{|c|}{ Expert family business advisors } \\
\hline Name & Age & Qualification & $\begin{array}{l}\text { Position of family business } \\
\text { advisor }\end{array}$ & \multicolumn{2}{|c|}{ FB: Years' experience } \\
\hline Business advisor 1 & 66 & $\mathrm{CA}(\mathrm{SA}) \& \mathrm{MBA}$ & Head of Advisory firm & \multicolumn{2}{|l|}{35} \\
\hline Business advisor 2 & 54 & Masters in Marketing & $\begin{array}{l}\text { Chief Operational Director: } \\
\text { FABASA }\end{array}$ & \multicolumn{2}{|l|}{18} \\
\hline \multicolumn{6}{|c|}{ Expert family business academic specialist } \\
\hline Name & \multicolumn{4}{|c|}{ Family business advisor expertise } & $\begin{array}{l}\text { FB: Years' } \\
\text { experience }\end{array}$ \\
\hline Academic 1 & \multicolumn{4}{|c|}{$\begin{array}{c}\begin{array}{c}\text { Director of the Nelson Mandela Metropolitan University (NMMU) Family Business Unit, the only one in } \\
\text { Africa. }\end{array}\end{array}$} & 13 \\
\hline
\end{tabular}

The unit of analysis of this research was the opinions of seven family business experts on multi-generational family business success. Ethical clearance was obtained from the Departmental Ethics Screening Committee (DESC) of the University of Stellenbosch Business School (USB) and participants signed informed consent forms. The family business experts were interviewed in their personal capacities. They all gave their consent for use of personal data.
After all the data from the interviews had been collected, it was analysed and similarities between the expert opinions were identified. The results were used to adjust and finalise the preliminary conceptual framework.

Although the context of this study is South Africa, the family business experts probed are internationally recognised through the global basis of their institutions. The outcome of the study is 
principles that could be universally applied in family businesses with an aspiration of sustainability over multi-generations.

In the next part, the content of the two research phases is described.

\section{Phase One: Development of A Preliminary Framework}

For the development of the preliminary conceptual framework for the FBSM, the concept of a family business is defined and the key aspects of the literature relevant to this study such as success practices for sustained performance of multi-generational family businesses are covered.

Before discussing the key aspects of successful practice, it is important to note that to make the FBSM framework userfriendly, we deemed it necessary to simplify the theoretical concepts for the application using an appropriate analogy. To increase the accessibility and ease-of-use of the final product as a one-page guide to family business stakeholders, the metaphor of a control panel of a boat is used where the control panel consists of items which give a visual picture of the most important aspects which a family business must consider in order to be sustainable for future generations (Figure 2).

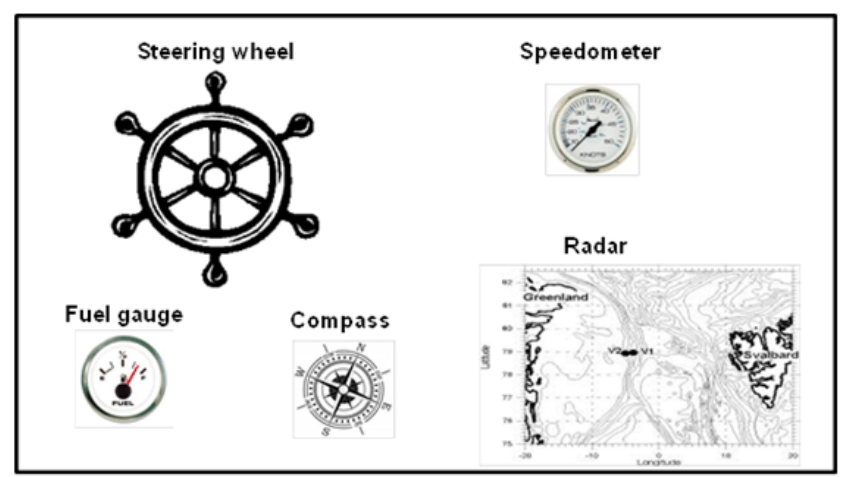

Figure 2: The control panel components

A short explanation of the elements and function of a control panel of a boat is necessary. A standard control panel consists of a flat panel with a variety of instruments, which need to be monitored regularly. A control panel furnishes the user with certain information to be used, in making informed decisions and, if necessary, appropriate adjustments to keep the boat on the right course. Because the control panel is the most important source of information to steer a boat on course and to safety, it is imperative that it be monitored on a continuous basis. Most of the instruments on a control panel will have some sort of warning indicator represented by a red light or by an alarm going off when something goes wrong. For the purpose of this study, the "boat" represents the family business and the control panel consists of the following five elements: a Steering wheel; Speedometer; Fuel gauge; Compass; and Radar. The meaning of each of the above control panel elements will be described as part of the identified key leverages per family business practice areas.

\section{Defining a Family Business}

Non-family businesses operate in two spheres consisting of the business sphere where the operational activities take place and the ownership sphere [8]. In family businesses, the family sphere is added to the business and ownership spheres [8]. All three of these systems influence the future success of a family business.

Family businesses have four characteristics: they are controlled by a single family; a certain number of family members are employed by the family business; they provide work for nonfamily members; and lastly, they have an independent board of directors supporting the goals and values of the controlling family [2]. [9] Concluded that almost all definitions of a family business take into account the role of the family in the formalisation of the vision and control of the business. The description of a family business this study used is from [10] who stated that a family business is one that is owned by members of the same family and the business is influenced by family ties to achieve the vision of the family over several generations.

The various practices as identified in the literature are presented next, followed by the tool accompanying each practice.

\section{Practices Followed By Successful Family Businesses}

The initial literature review of this study identified the following five key practices that successful family businesses follow to ensure the long-term sustainability of their businesses: succession planning, the role of the board, family meetings, strategic planning, and the use of financial planning and management accounts. These practices largely support comprehensive reviews on best family business practices for multiple generational successes [11-13]. It should be noted that the literature suggests hundreds of related practices with theme variations [11]. The intent here is only to focus on an initial set of key leverages in family business practice areas that a family business should consider continuously in order to stimulate multi-generational sustainability. These practices areas were evaluated and updated in the second phase of the research.

\section{The Role of Succession Planning}

Succession planning is one of the most critical issues a family business faces as this is the key to the survival of the family business from generation to generation [14, 15]. [16] Indicated that this transfer of family business ownership and management is a complex and challenging process which arises from the different personal, business, and financial objectives to be achieved. [14] Showed that family business founders' reluctance to plan for succession is due to the founders' strong sense of attachment to the business, fear of retirement and death, and a lack of other interests. [3] Argued that many family businesses do not have a next generation successor available. A successor needs a special set of skills to manage and develop the business. Sometimes the next generation carries the burden of stepping into big shoes and the fear of failure keeps them from taking the necessary risks to grow the business [3]. The success of a succession can be measured by the satisfaction of the stakeholders 
with the succession process as well as a positive performance by the family business after the succession has been completed.

Succession planning is a process over time and can consist of different phases [2]. Therefore, it is important that every family business should have a succession plan in place and it should be revisited and evaluated regularly. No two family businesses are the same and this feature makes it difficult to have one single theory for understanding successions [17]. A key aspect of the succession process is the timing of succession. [18] Indicated research that shows that the life-stage combination of the father and son can either facilitate succession or aggravate the tensions that accompany it. Succession planning is a mechanism to assist in making succession smoother. [18] Further indicated that it is important to make sure that the next generation is both interested in joining the family business and capable of managing it.
The metaphor used for succession planning is the steering wheel on a boat which turns the boat in the direction indicated by the rest of the instruments. However, the steering wheel can also take the boat on the wrong course if the information fed to it is wrong or inadequate. As indicated above, research shows that succession in family businesses is one of the most crucial processes the family has to deal with. To provide the steering wheel with valid information for action, a decision-making process should be used, as illustrated in the diagram below (Figure 3), in which important aspects of the succession process are highlighted. Mentoring of and good support for the successor are some of the practices used by successful family businesses to ensure successful succession [3]. (Figure 3)

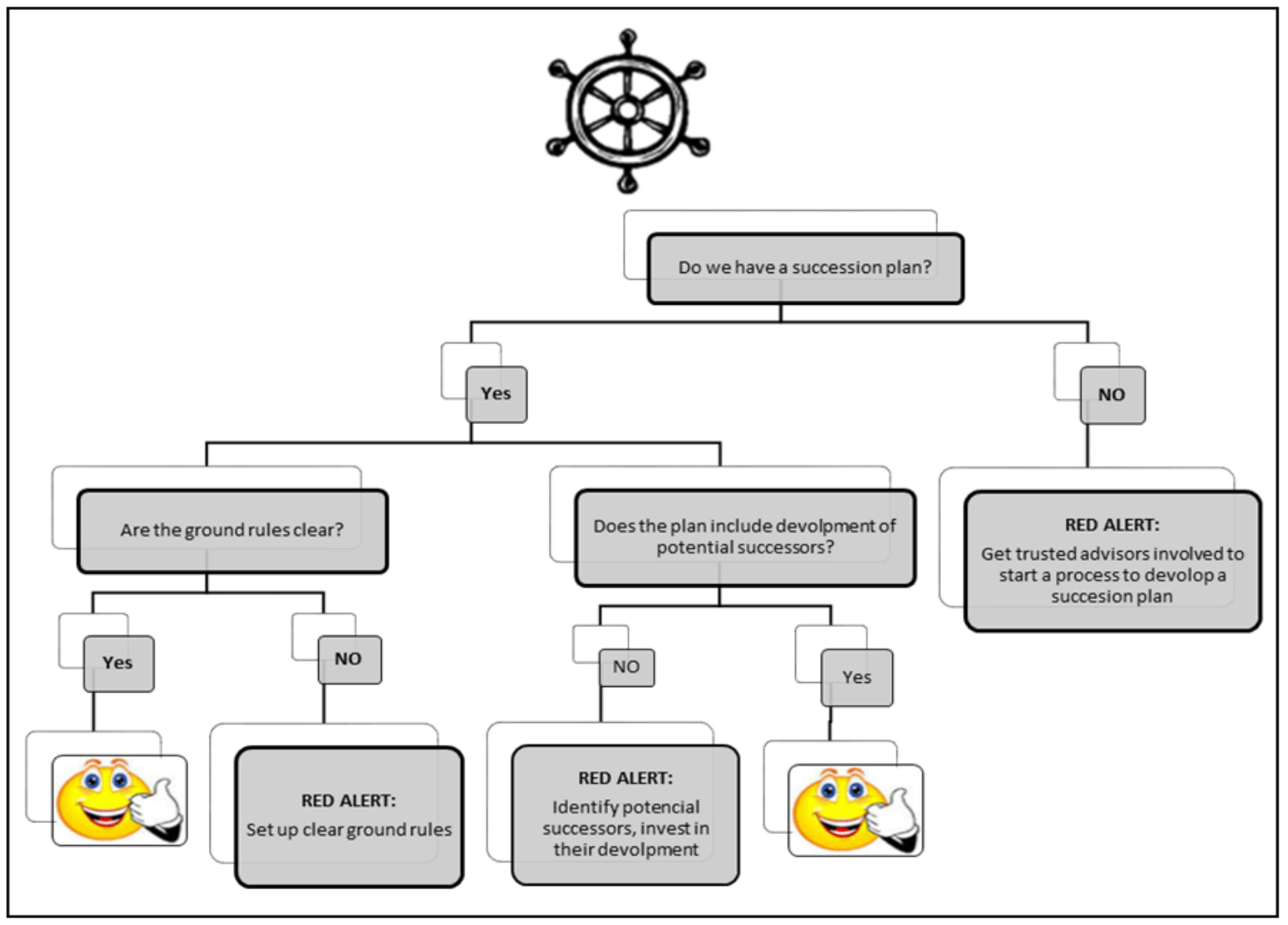

Figure 3: Succession decision diagram

\section{The Role of the Board as Leaders}

For this study, the term "the Board" is used to refer to the business governance body of a family business and can consist of a combination of family, non-family, and independent members. [19] Stated the accountability of the board of directors as a central theme of corporate governance. Even more important, they highlighted that in family businesses this accountability involves the importance of not sacrificing long-term health of the family business for short-term gains. According to [19], the board of directors must have the ability of strategic guidance of the business, for effective monitoring of management, for maintaining open communications and having a basic understanding of business risks and financial matters. Several authors [19, 20, 3] have indicated that outside members on a board can contribute unbiased expertise on matters such as executive remuneration, succession planning, changes in corporate control, merger and acquisitions, as well as the audit function. Every board should have a board manual. The board manual may include, inter alia, information like the company's values, the strategic plan of the business, the goals, and the evaluation processes [19]. 
The metaphor used for board leadership is a speedometer. The purpose of a speedometer is to measure and display the speed of a vehicle [21]. Leadership in a family business plays an important role in the speed at which the business grows. According to [3], family businesses fail because they destroy themselves through leadership which fails to take action timeously. The importance of a competent board of directors who can act timeously was identified by [22] as key to the success of old and successful multiple-generation family businesses. Experience, some independent directors, and directors closely involved in the business, are some of the characteristics that [23] found on the boards of successful family businesses. Figure 4 provides an illustration of the decision tree when evaluating the board leadership practices within a family business. (Figure 4)

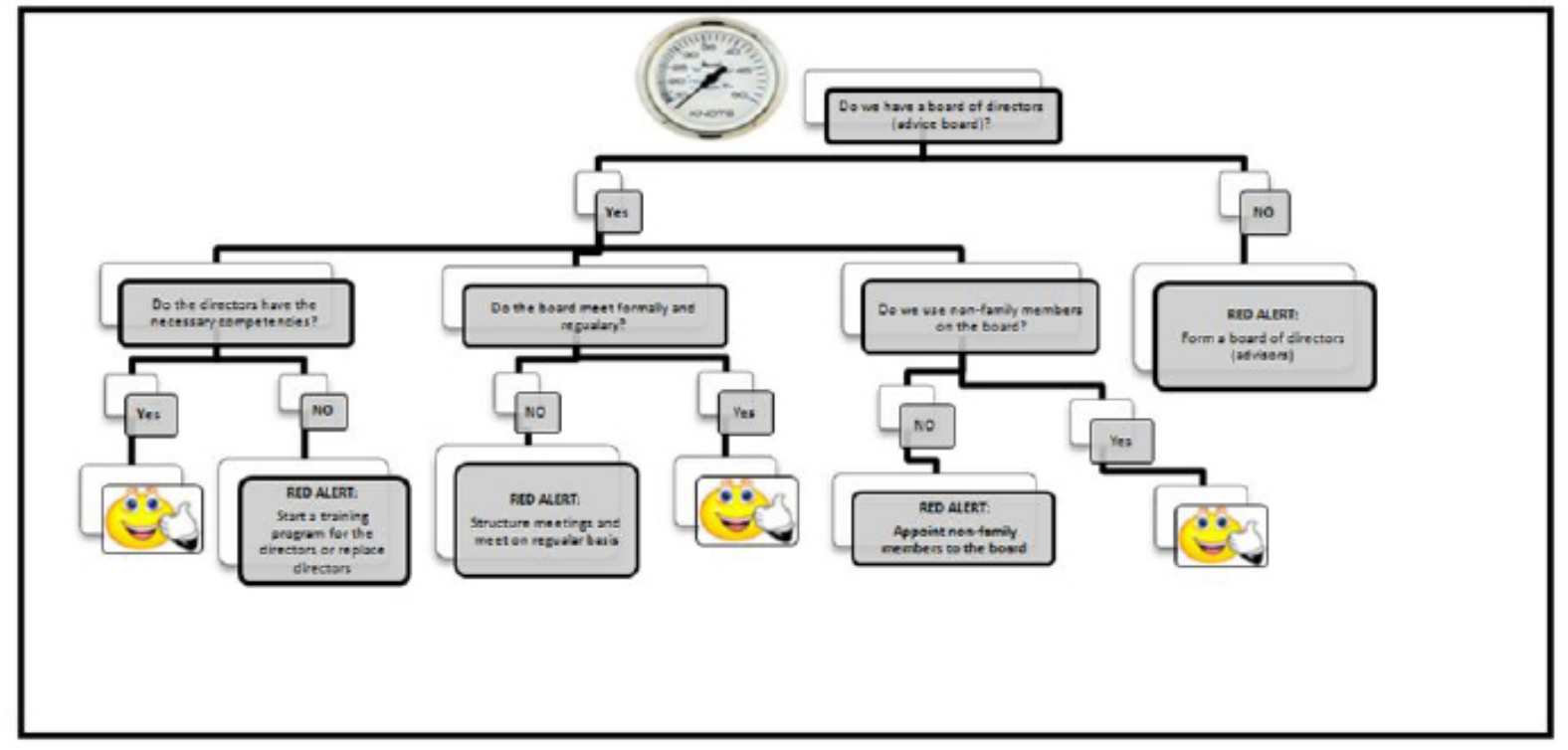

Figure 4: Board leadership decision diagram

\section{The Role of Family Meetings to Foster Family Harmony}

Family meetings develop unity about goals, desires, and actions and this unity and harmony become the basis for positive results in a family business [24]. [22] Found that family businesses holding regular family meetings expected significant growth.

Family meetings, governed by a family council, are important in handling family disputes and conflicts. Family meetings constitute an important forum for developing consensus around key issues and to foster family harmony [25, 20]. [3] Stated that the most important best practice for a family business to be sustainable is to hold family meetings. Ward indicated that the purpose of these meetings must be to define the family mission, values, and motivations to continue as a family business. [10] Confirmed this when they highlighted the fact that many successful family businesses hold family meetings to discuss family matters rather than pure business-related issues. During these meetings, the family vision and the family constitution, which represent principles for sustaining the family business, are revisited. Aspects like family highlights of the year, family bonding, and team-building activities are also on the agenda to promote harmony [18]. Family meetings should also include fun activities and should transfer family culture and history to the next generation [10].

In the control panel analogy, the fuel gauge measures the family harmony where a full reading represents a very high degree of harmony among family members. The position of the fuel gauge dial on the control panel should be as near to full as possible. The more harmonious family relationships are, the better their chances for a long-term sustainable future for their family business [6]. [6] Identified family relationship issues as a primary threat to the growth and survival of family businesses. The holding of regular family meetings to address both business and family-related matters is an important mechanism to sustain family harmony $[22,6]$. Figure 5 provides an illustration of the decision tree when evaluating the family harmony within the family business through having family meetings. (Figure 5)

\section{The Role of the Strategic Plan}

Researchers agree that one of the things successful family businesses have in common is that they all have a formal, written strategic and/or business plan [22, 26-28]. [29] However indicated that non-family businesses are 2.7 times more likely to have a formal strategic or business plan than family businesses. [28] showed that the successful family businesses shared this plan and its performances with all their employees, not only with family members. [27] found that family businesses with written strategic plans generate a better profit improvement than family businesses without formal plans. [10] Confirmed this perspective underlining the importance of planning for growth and making future-orientated strategic investments. They also highlighted the importance of business meetings being organised, formal and structured with a strategic and operational framework agreed to by management and separate family meetings focusing on family matters [10]. 


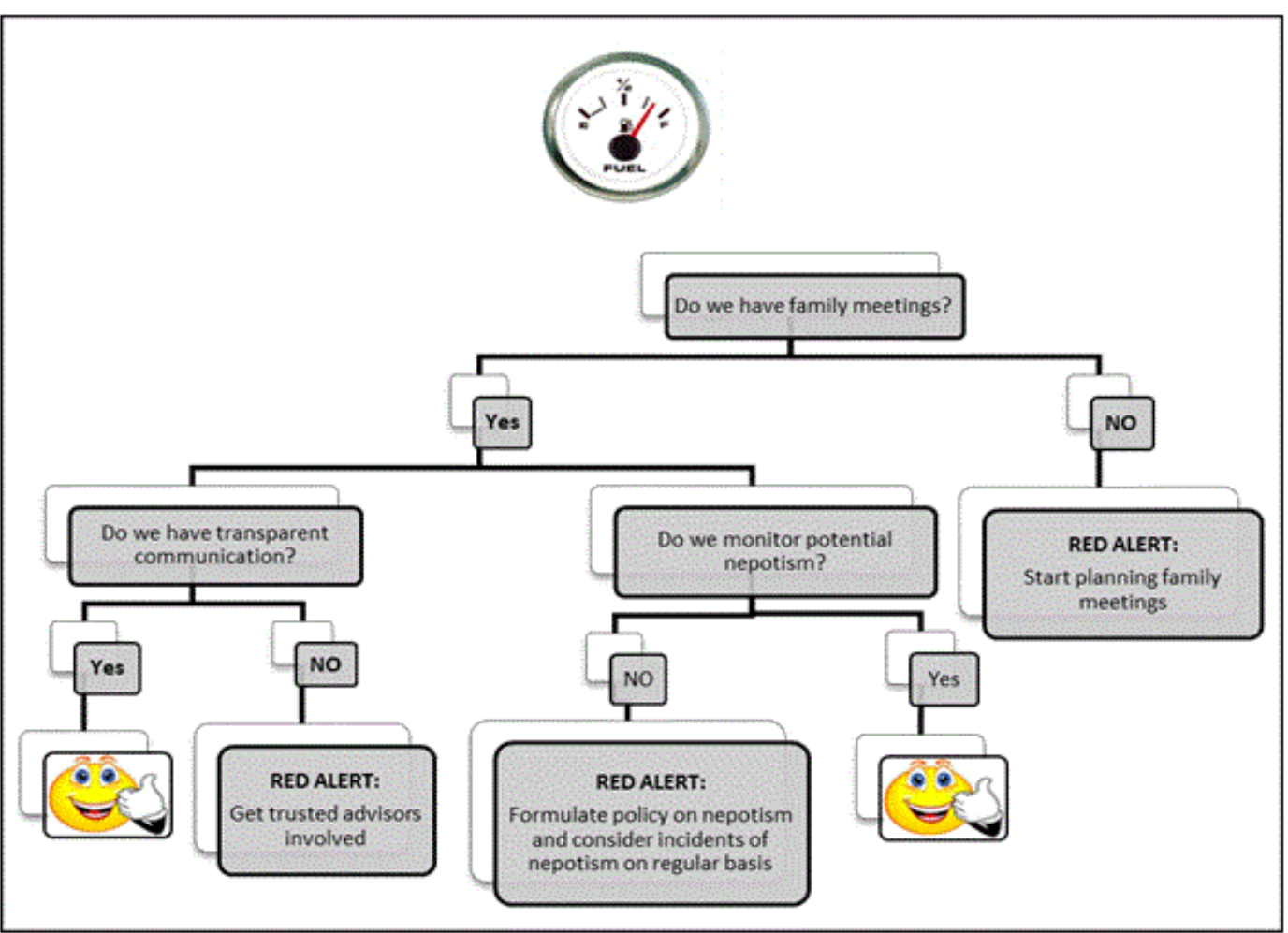

Figure 5: Family harmony decision diagram

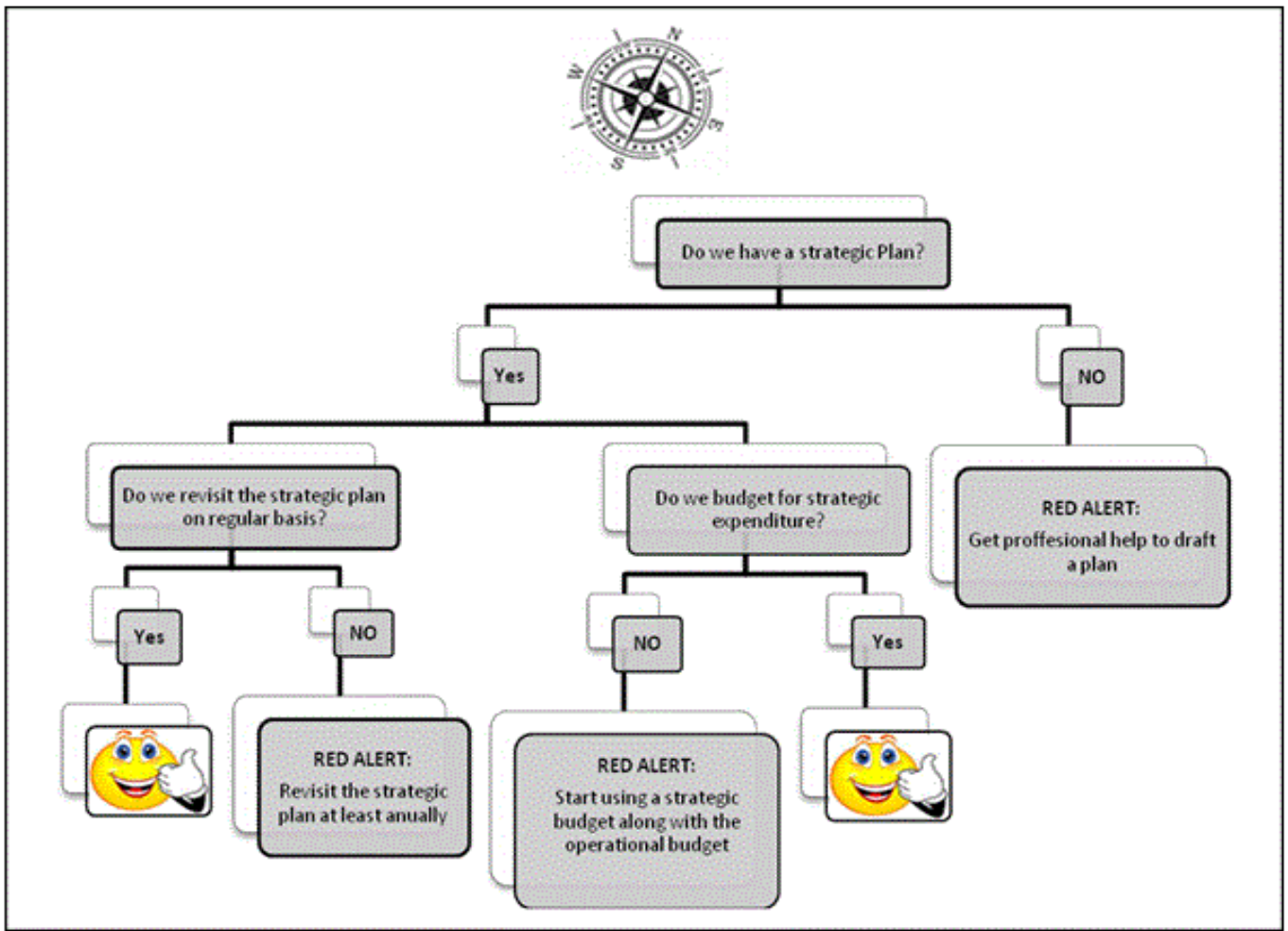

Figure 6: Strategic plan decision diagram 
The metaphor used for a strategic plan is a compass because as a navigational instrument it indicates the direction [21]. In a family, the strategic plan is the most important document that is being used to give direction. Figure 6 gives a decision diagram that should be used when evaluating the 'compass' function on the control panel. (Figure 6)

\section{The Role of Cost Management Accounting Practices as Part of Financial Management}

One of the reasons [8] highlighted for the high mortality rate of family businesses is the pattern that family businesses use fewer management accounting instruments and normally do not have specialised management accounting capacities. He also stated that family business managers may lack crucial information about the top-performing and underperforming areas of the business as well as the current risks of the business. [30] Stated that the proactive use of management accounting practices is a potential cure for family business failures and that practices such as budgeting and the balanced scorecard assist the family member to codify their implicit knowledge and to formalise the strategic planning process of the family firm.

The three subsystems of a family business, namely the business system, the ownership system, and the family system [8] benefit from using management accounting practices in the following ways. The family system benefits through management accounting as a way to codify and classify knowledge [30] to contribute to business successions through the transfer of knowledge. To illustrate this point, [8] provided the example of the family owner writing down (and therefore codifying) both the financial and non-financial goals of the family business for the next few years. Future generations will then better understand the strategic objectives the founder had when running the business. It will also help them to examine individual goals and give an understanding of who must contribute what to reach the overall targets. [8] Also indicated that when family members are not actively engaged in the management of the family business anymore, management accounting could provide the tools to monitor non-family managers and to make their actions more transparent for the controlling family. The use of annual budgets creates one-year goals for managers. The controlling family can set targets and therefore influence the target earnings. Management accounts and financial management information will help to prove whether the targets are met and if not, what the reasons for this are [8]. The ownership system of family businesses usually prefers debt to equity financing for the growth of the firm. Financial institutions are unlikely to lend money without receiving regular information on the performance of the company. This information required by creditors or banks should be produced by the management accountants [8]. The business system benefits from the proper use of management accounting as it creates transparency and delivers facts for decision making. According to [31], 'familiness', the interaction that there is between family and the family business, is often more important than other goals and therefore decisions are not always based on facts alone. [8] Stated that facts derived from management accountants are the first step toward more fact-based decisions.
Business continuity will be fostered by the knowledge-codifying character of management accounting information [8].

The radar function on the control panel represents the practice of a business to detect pro-actively cost-related and other financial information in order to support management to achieve the strategic goals of the family business. Management accounting provides information, not only on where the business finds itself but also on where it is heading and the associated risks [32]. Figure 7 offers a decision diagram for this purpose. (Figure 7)

The outcome of phase one is the preliminary framework to enhance multi-generational sustainability for family businesses.

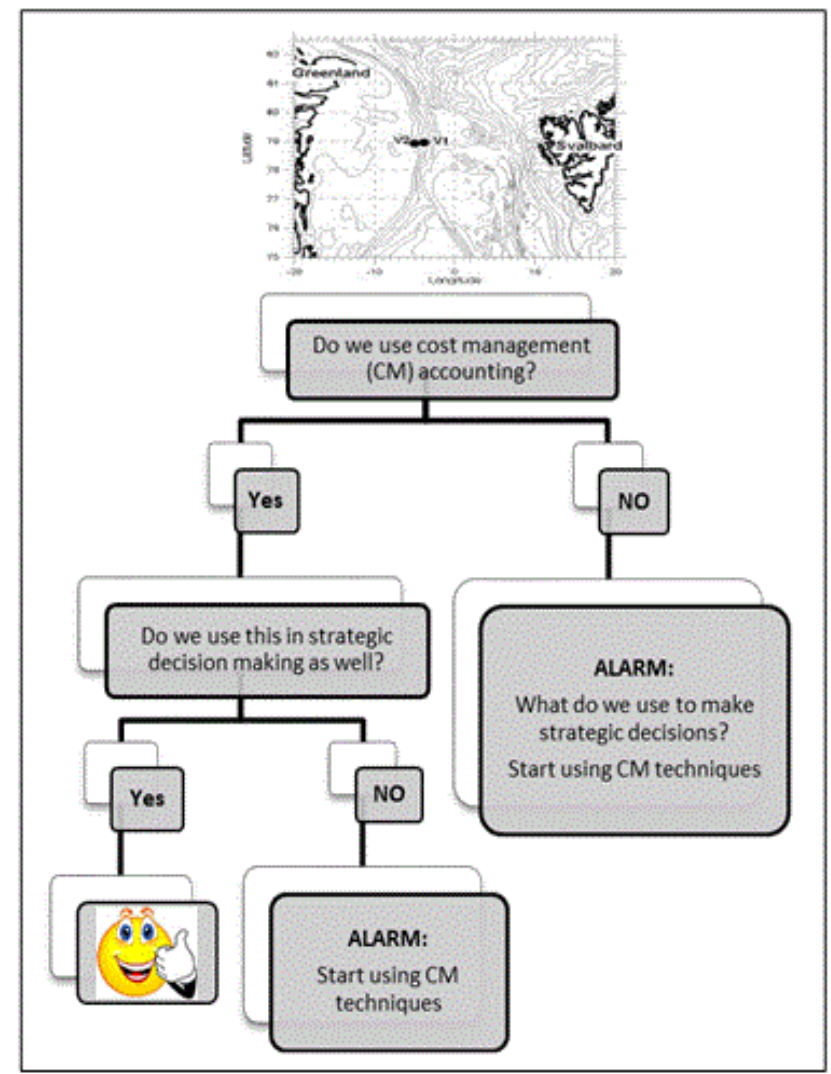

Figure 7: Cost management accounting decision diagram

\section{Preliminary Framework}

The preliminary framework provides a visual representation of the key theoretical leverages from the existing literature and is a practical accessible tool to aid family businesses in their quest to be sustainable over multi-generations. (Figure 8 )

In the next part, the findings from phase two of the research are reported, the results of the interviews with seven family business experts. The outputs of these interviews, which were used to evaluate and improve the preliminary framework, are presented as an integrated FBSM. 


\begin{tabular}{|c|c|c|c|c|c|c|}
\hline \multicolumn{7}{|c|}{ Figure 8: The preliminary framework for multi-generational } \\
\hline Symbol & Instrument & $\begin{array}{c}\text { Critical } \\
\text { element }\end{array}$ & Academic references & $\begin{array}{l}\text { Questions to } \\
\text { ask }\end{array}$ & Yes & No \\
\hline & $\begin{array}{c}\text { Steering } \\
\text { wheel }\end{array}$ & $\begin{array}{c}\text { Succession } \\
\text { planning } \\
\text { practice }\end{array}$ & $\begin{array}{l}\text { Blumentritt et al. (2013) } \\
\text { Filser et al. (2013) } \\
\text { Venter (2007) } \\
\text { Ward (1997) }\end{array}$ & $\begin{array}{l}\text { Do we have a succession plan? } \\
\text { Are the ground rules for } \\
\text { succession clear? } \\
\text { Does the plan include } \\
\text { development of potential } \\
\text { successors? }\end{array}$ & & \\
\hline & Speedometer & $\begin{array}{l}\text { Leadership } \\
\text { practice }\end{array}$ & $\begin{array}{l}\text { Aronoff and Astrachan (1996) } \\
\text { Lane et al. (2006) } \\
\text { Le Breton-Miller et al.(2004) } \\
\text { Ward (1997) } \\
\text { Wilson et al. (2013) }\end{array}$ & $\begin{array}{c}\text { Do we have a board of directors? } \\
\text { Does the board of directors meet } \\
\text { regularly? } \\
\text { Are there non-family members on } \\
\text { the board? } \\
\text { Do directors have the } \\
\text { competencies to act responsibly, } \\
\text { timeously and are they } \\
\text { accountable? }\end{array}$ & & \\
\hline & Fuel gauge & $\begin{array}{c}\text { Family } \\
\text { harmony } \\
\text { practice }\end{array}$ & $\begin{array}{l}\text { Astrachan and Habbershon } \\
\text { (1997) } \\
\text { Aronoff and Astrachan (1996) } \\
\text { Le Breton-Miller et al. (2004) } \\
\text { Maas and Diederichs (2007) } \\
\text { Ward (1997) } \\
\text { Zachary (2011) }\end{array}$ & $\begin{array}{c}\text { Do we have family meetings? } \\
\text { Do we have transparent } \\
\text { communication? } \\
\text { Do we monitor potential } \\
\text { nepotism? } \\
\text { Do we foster family harmony in } \\
\text { our family practices? }\end{array}$ & & \\
\hline & Compass & $\begin{array}{l}\text { Strategy } \\
\text { practice }\end{array}$ & $\begin{array}{c}\text { Aronoff and Astrachan } \\
\text { (1996:52) } \\
\text { Maas and Diederichs (2007) } \\
\text { Peters and Buhalis (2004) } \\
\text { Smith (2007) } \\
\text { Upton et al. (2001) }\end{array}$ & $\begin{array}{l}\text { Do we have a strategic plan? } \\
\text { Do we revisit our strategic } \\
\text { plan on a regular basis? } \\
\text { Do we involve our trusted } \\
\text { advisors in the process? }\end{array}$ & & \\
\hline 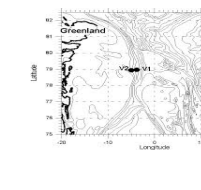 & Radar & $\begin{array}{c}\text { Financial } \\
\text { management } \\
\text { practice }\end{array}$ & $\begin{array}{l}\text { Giovannoni et al. (2011) } \\
\text { Hiebl (2013) } \\
\text { Sirmon and Hitt (2003) } \\
\text { Blocher et al. (2010) }\end{array}$ & $\begin{array}{l}\text { Do we use cost management } \\
\text { accounting? } \\
\text { Do we use cost management } \\
\text { accounting in our strategic } \\
\text { decision-making? }\end{array}$ & & \\
\hline
\end{tabular}

\section{Phase Two: Validation of the Framework}

When asked to name the most critical practice a family business should follow to be sustainable over multi-generations, the seven experts had related responses, indicating that family businesses need to be more structured and professional if they want to survive for multiple generations (Table 3).

The above perspectives from the family business experts highlight the importance of formal policies to cover the three spheres of a family business, specifically ownership, business, and family. It gives the family business the means to deal with a variety of difficult and sometimes unpleasant situations. Successful family businesses follow a commercial approach as the business outgrows the family and the family must be bold enough to acknowledge it. There must be a formal separation between the business and the family.
The evaluation results of the experts on the preliminary FBSM are reflected in Table 4 which summarises the average importance rating per critical element given by the seven experts for the five critical practices. It is interesting to note that on a comparative basis the strategic plan practices and cost management practices as reflected in the preliminary FBSM are viewed as the most important for multi-generational success. (Table 4)

All of the family business experts accepted the preliminary framework as a potential tool which family businesses could use to guide them to be more structured and to be more sustainable. The total average score of the preliminary framework was 7.4, indicating a relatively high importance rating for the five identified business practices. Table 5 provides some of the positive and negative responses by the family business experts on the preliminary framework for family business success. (Table 5) 


\begin{tabular}{|c|l|}
\hline Table 3: Family business experts: & most critical family business practice \\
\hline Family member $\mathbf{1}$ & $\begin{array}{l}\text { "It is a dynamic environment. For the transfer from entrepreneurship one needs to continuously establish } \\
\text { structures as the business grows. The family business must become more structured. It becomes a more } \\
\text { corporate environment". }\end{array}$ \\
\hline Family member $\mathbf{2}$ & $\begin{array}{l}\text { "For a family business to grow in order to become a sustainable business over generations it must be driven by } \\
\text { business principles. The business principles must be stronger than the family principles". }\end{array}$ \\
\hline Family member $\mathbf{3}$ & $\begin{array}{l}\text { "To educate the next generation on the current dream of the business". He later added that all decisions must } \\
\text { make business sense, a family business must not be sentimental. }\end{array}$ \\
\hline Family member $\mathbf{4}$ & "Must be very professional, your product must be excellent and you must be honest". \\
\hline Business advisor $\mathbf{1}$ & $\begin{array}{l}\text { "You have family businesses that remain only family businesses and then you have family businesses that are } \\
\text { managed professionally. That is the big difference!" }\end{array}$ \\
\hline Business advisor $\mathbf{2}$ & $\begin{array}{l}\text { "The business must be structured and when someone is identified to be the successor it must be in the interest of } \\
\text { the business". }\end{array}$ \\
\hline Academic $\mathbf{1}$ & $\begin{array}{l}\text { "They need to have proper governance structures and procedures in place for all of the ownership, management } \\
\text { and family systems". }\end{array}$ \\
\hline
\end{tabular}

Table 4: Average importance rating by family business experts

\begin{tabular}{|c|c|}
\hline Critical element & Average importance rating (10: very high - 1: very low) \\
\hline Succession planning practice & 7.14 \\
\hline Leadership practice & 8.57 \\
\hline Family harmony practice & 8.28 \\
\hline Strategic plan practice & 8.16 \\
\hline Cost management accounting practice & 7.4 \\
\hline Total average score & \\
\hline
\end{tabular}

Table 5: Positive and negative responses on the preliminary framework

\begin{tabular}{|c|c|c|}
\hline Expert & Positive response & Negative response \\
\hline Family member 1 & "Very comprehensive list, it is the things that we do". & None \\
\hline Family member 2 & "Very good, I think excellent". & None \\
\hline Family member 3 & "I think it is spot-on, very well thought through". & None \\
\hline Family member 4 & "In general good". & $\begin{array}{c}\text { "I do not know if it comes out clearly but } \\
\text { communication is very important and the lack of } \\
\text { communication very dangerous". }\end{array}$ \\
\hline Business advisor 1 & "I think it is a very good combination". \\
\hline Business advisor 2 & "These are very good elements". & $\begin{array}{c}\text { "Maybe I would have grouped some of the elements } \\
\text { differently". }\end{array}$ \\
\hline Academic 1 & "It is visual and easy to understand". & $\begin{array}{c}\text { "Succession should also clearly distinguish } \\
\text { between management and ownership succession. } \\
\text { What about entrepreneurial orientation?" }\end{array}$ \\
\hline
\end{tabular}

A clear shortcoming of the preliminary framework is that it does not address ownership succession, as recommended by one of the experts. This could be important for some family businesses and an additional question was added to the final framework under the succession planning practice to address this aspect.

The family business experts raised three additional practices areas that in their view are important for multi-generational family business success, namely Governance, Entrepreneurial orientation, and Communication.

Two types of governance practices are important for a family business, namely family-orientated and business-orientated governance. The family-orientated governance aspects include the determination of shared family values to foster pride and to protect the interest of the business; the maintenance of a financial mandate within which the business must operate; space to address unhealthy rivalry between family members; and principles for the appointment of family members in the business. A formal family council and family constitution with ground rules to focus on family interests and issues related to the family and ownership spheres are required. The family-orientated governance aspects are addressed in the two family practices of 
leadership - and family harmony practices (Figure 8). Businessorientated governance relates to the application of generally accepted best practices in corporate governance, for example King IV (IODSA, 2016). A formal corporate governance approach is seen by Business advisor 1 as essential to prevent the situation where emotions rule the business which is an infallible recipe for disaster. An advisory council, preferably with some outside members, to guide the business for sustainable performance based on a best-in-class corporate governance approach is seen by Family member respondent 2 to be important. The family business experts agree that without proper governance structures, communication will always be a problem, leading to a situation where emotions rule the business which is an infallible recipe for disaster. Good governance choices are critical for family business success $[34,18]$. The important aspect of business and family-orientated governance is added in the final FBSM.
The family business experts indicated that the developing of an entrepreneurial orientation is critically important because without entrepreneurship and innovation it is difficult for the family business to grow and accommodate the next generation. Where the family grows faster than the business, trouble is unavoidable. They believe a family business needs to be at the forefront of technology in the business terrain of its expertise. To achieve this, they indicate that you need to be entrepreneurialorientated. They also feel that successful family businesses should have the ability to transfer the entrepreneurial characteristics of the business from one generation to the next. The business environment changes all the time and family businesses must develop the ability to adapt to the new way of life. Academics guide that the criticality of an entrepreneurial orientation in family firms contributes to "trans generational succession when it endures across generations" $[35,13]$.Subsequently, the aspect of developing an entrepreneurial practice in a family business is added to the final view of the FBSM.

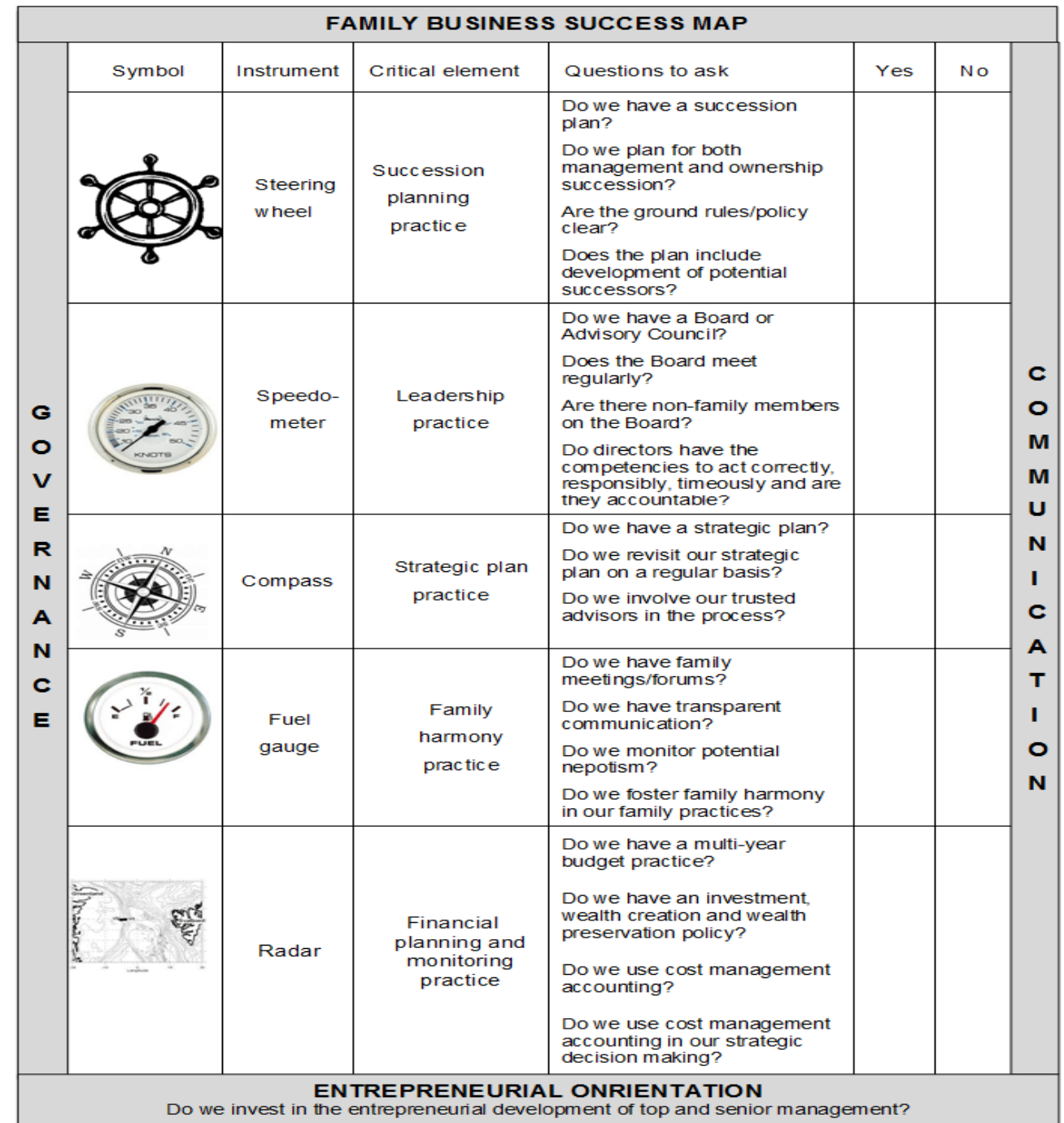

Figure 9: Revised FBSM 


\section{A Family Business Success Map to Enhance the Sustainability of a Multi-Generational Family Business}

The family business experts pointed out communication as very important success leverage for both the business system and the family system. According to these experts, feedback on a continuous basis along with proper formal employee performance evaluations, for family and non-family members, is crucial for survival. This includes the building of trust and the acknowledgment of everyone's position through ongoing communication practices. Communication practices are linked to family harmony practices [11] and leadership practices [19] as reflected in Figure 9. Communication as an ongoing practice in family businesses is the last additional aspect added to the FBSM.

The outcome of the second phase of this study is a concise onepage FBSM which shows some of the key management practices that could be leveraged on an ongoing basis for the enhancement of the sustainability of multi-generational family businesses. The final version of the revised Family Business Success Map based on the views expressed by family business experts is shown in Figure 9. The sequence of the critical practices was changed in order to accommodate some groupings suggested by the experts; the questions under succession planning, family harmony and financial planning were expanded; and the three aspects of governance, entrepreneurial orientation, and communication were added. Governance and communication are the two pillars holding the FBSM together, while entrepreneurial orientation forms the foundation of any family business. (Figure 9)

\section{Conclusion and Recommendations}

A user-friendly FBSM was developed using a two-phased approach as reported in this article in response to the vulnerability of family businesses over multiple generations. There are eight key leverages that family business stakeholders like family business members, family business advisors, and family business managers can use to enhance the sustainability of a multi-generational family business. The revised FBSM is an integrated, easy accessible managerial framework on one page that assists and stimulates users to evaluate and benchmark their current business practices against the identified family business practice areas. These eight key family business practice areas can be used as a starting point of reference to assess current practices to identify gaps and improvement focus area for sustainable performance of multi-generational family businesses. The intent with the FBSM is to stimulate constructive dialogue between the various stakeholders of a family business to enhance the longerterm sustainability of the business.

The limitations of the current study are associated with the small group of family business experts used and the fact that the study focused on small- to medium-sized family enterprises and not on major listed family companies. The results from the study should be interpreted within these limitations and context. Unintentionally, it just so happened that six of the seven family business experts were male and all of them were from the Western Cape in South Africa. The academic expert was female and from the Eastern Cape. Cultural differences in family businesses were not addressed.
The FBSM as reflected in this study is not an all-encompassing view on this broad subject matter, but rather a conversation stimulus to explore important management practice leverages to improve the sustainability of a family business over multigenerations. It is also important to note that [12] indicated that not all family businesses aspire to exist over multi-generations. The FBSM is therefore aimed at only those family businesses with multi-generational longevity as a strategic intent.

The following future research related to aspects of the FBSM is a possibility:

1. Further explore and test with more family business experts, evaluating the FBSM and expressing their expert opinions.

2. Enhance, expand and validate the management practice leverages associated with the FBSM through a quantitative study.

3. Explore the cultural implications on the governance practices of different ethnic groups.

4. Evaluate the impact of early identification and development of successors on the sustainability of family businesses.

5. Evaluate the governance differences and similarities between the advisory councils and family councils in family businesses.

6. Investigate the implications of ownership succession on the longevity of the family business.

The main contribution of this study is a relatively modest benchmark tool to assist family businesses and its advisors to identify improvement areas for sustainable performance of multi-generational businesses. Family business success that spans multi-generations is not a once-off intervention, but the continuous leveraging of key business practices.

\section{References}

1. Stalk G, Foley H. Avoid the traps that can destroy family businesses, Harvard Business. 2012; 90(1).

2. Venter WP, Kruger S, Herbst F.J. The role of familiness in the success or failure of family-business groups. Unpublished PhD thesis, Dept. of Business Management, University of Johannesburg. 2007.

3. Ward JL. Growing the family business: Special challenges and best practices, Family Business Review. 1997; 10(4): 323-337. DOI: 10.1111/j.1741-6248.1997.00323.x

4. Strike VM. The most trusted advisor and the subtle advice process in family firms, Family Business Review. 2013; 26(3): 293-313. DOI: 10.1177/0894486513492547

5. Memili E, Addleston KA, Kellermanns FW, Zellweger TM, Barnett T. The critical path to family firm success through entrepreneurial risk taking and image, Journal of Family Business Strategy. 2010; 1(4): 200-209. DOI: 10.1016/j.jfbs.2010.10.005.

6. Venter E, Van der Merwe S, Farrington, S. The impact of selected stakeholders on family business continuity and family harmony, Southern African Business Review. 2012; 16(2): 69-96.

7. Duh M, Belak J Milfelner B. Core values, culture and ethical climate as constitutional elements of ethical behaviour: Exploring 
differences between family and non-family enterprises, Journal of Business Ethics 2010; 97(3): 473-489. DOI: 10.1007/s10551010-0519-9.https://link.springer.com/article/10.1007/s10551010-0519-9

8. Hiebl M.R.W. Management accounting in the family business: Tipping the balance for survival, Journal of Business Strategy. 2013; 34(6): 19-25. DOI: 10.1108/JBS-07-2013-0052

9. Sharma P. An overview of the field of family business studies: Current status and directions for the future, Family Business Review. 2004;17(1),1-36. DOI: 10.1111/j.1741-6248.2004.00001

10. Maas G, Diederichs A. Manage family in your family business, Frontrunner Publishing, Northcliff. 2007.

11. Dana LE, Smyrnios K S, Bi R. Family business continuity: Key factors and main practices, 28th Annual Conference proceedings of the Small Enterprise Association of Australia and New Zealand, 2015; 1-15.

12. Dana L E, Smyrnios K S. Family business best practices: Where from and where to? Journal of Family Business Strategy. 2010; 1(1): 40-53. DOI: 10.1016/j.jfbs.2009.12.002.

13. Habbershon T, Williams M L, MacMillan I C. A unified systems perspective of family firm performance, Journal of Business Venturing. 2003; 18(4): 451-465. DOI: 10.1016/S08839026(03)00053-3

14.Filser M, Krau S, Märk S. Psychological aspects of succession in family business management, Management Research Review. 2013; 36(3): 256-277. DOI: 10.1108/01409171311306409

15. Ward J L. Keeping the Family Business Healthy: How to Plan for Continuing Growth, Profitability, and Family Leadership, New York, Palgrave MacMillan. 2011

16. Holland M L, Holland P G. Reconciling management and financial objectives in family business succession and estate planning, The Entrepreneurial Executive. 1995; 1(1): 53-58.

17. Blumentritt T, Mathews T. Marchisio G. Game theory and family business succession: An introduction, Family Business Review. 2013: 26(1); 51-67. DOI: 10.1177/0894486512447811.

18. Sharma P, Chrisman J J, Chua J H. Strategic Management of the Family Business: Past Research and Future Challenges, Family Business Review. 1997: 10(1); 1-35. DOI: 10.1111/j.17416248.1997.00001.

19. Lane S, Astrachan J, Keyt A, McMillan K. Guidelines for family business boards of directors, Family Business Review. 2006: 19(2); 147-167. DOI: 10.1111/j.1741-6248.2006.00052.

20. Le Breton-Miller I, Miller D, Steier L P. Toward an integrative model of effective FOB succession, Entrepreneurship Theory and Practice. 2004: 28(4); 305-328. DOI: $10.1111 / \mathrm{j} .1540$ 6520.2004 .00047
21. Hornby A S. Oxford advanced learners dictionary, Oxford University Press, London. 1974.

22. Aronoff C E, Astrachan J H. Reducing the risks of family-business growth, Nation's Business. 1996: 84(3); 52-53.

23. Wilson N, Wright M, Scholes L. Family business survival and the role of boards, Entrepreneurship Theory and Practice 2013: 37(6); 1369-1389. DOI: 10.1111/etap.12071.

24. Astrachan J H, Habbershon T G. Research note perceptions are reality: How family meetings lead to collective action, Family Business Review. 1997: 10(1); 37-52. DOI: 10.1111/j.17416248.1997.00037.

25.Zachary R.K. The importance of the family system in family business, Journal of Family Business Management. 2011: 1(1); 26-36. DOI: 10.1108/20436231111122263.

26. Miller D, Le Breton-Miller I. Managing for the long run: Lessons in Competitive Advantage from Great Family Businesses, Harvard Business School Press, Boston. 2005

27. Peters M, Buhalis D. Family hotel businesses: Strategic planning and the need for education and training, Education \& Training. 2004: 46(8/9): 406-415. DOI: 10.1108/00400910410569524

28.Upton N, Teal E J, Felan J T. Strategic and business planning practices of fast growth family firms, Journal of Small Business Management. 2001. 39(1), 60-72. DOI: 10.1111/04472778.00006.

29. Smith M. 'Real' managerial differences between family and non-family firms, International Journal of Entrepreneurial Behaviour \& Research. 2007. 13(5), 278-295. DOI: 10.1108/13552550710780876.

30.Giovannoni E, Maraghini M P, Riccaboni A. Transmitting knowledge across generations: The role of management accounting practices, Family Business Review. 2011. 24(2), 126150. DOI: $10.1177 / 0894486511406722$.

31. Sirmon D G, Hitt M A. Managing resources: Linking unique resources, management, and wealth creation in family firms, Entrepreneurship Theory and Practice. 2003. 27(4), 339-358. DOI: 10.1111/1540-8520.t01-1-00013.

32. Blocher E J, Stout D E, Cokins G. Cost management, a strategic emphasis, McGraw-Hill/Irwin, New York. 2010.

33.Institute of Directors of South Africa (IODSA), 2016, King IV Code on Corporate Governance for South Africa, 2016, Institute of Directors South Africa, Johannesburg.

34. Miller D, Le Breton Miller I. Family Governance and Firm Performance: Agency, Stewardship, and Capabilities, Family Business Review. 2006, 19(1), 73-87. DOI: 10.1111/j.17416248.2006 .00063$.

35.Chrisman J J, Chau J H, Steier L P. An introduction to theories of family business, Journal of Business Venturin. 2003. 18, 441448. DOI: 10.1016/S0883-9026(03)00052-1 